\title{
Labor and Production
}

\author{
By W. JetT Lauck \\ Formerly Secretary of War Labor Board
}

B EFORE the outbreak of the World War there was, and because of stimulated immigration there had been for some years, a surplus labor supply for our basic industries. At the present time there is a shortage of labor. The determining factor as to stability and acceleration of production has, therefore, been reversed. The efficiency of capital and management were the controlling forces before the war. The primary problem to be considered in any future program for industry now centers about the effectiveness of labor.

\section{Difficulty of Present Industrial and Political Problems}

It may be stated without any attempt at sensationalism and without danger of contradiction, that our country is facing today the most complex, dangerous and difficult situation which it has been confronted with since the close of the Civil War. The old order has passed. A new era is before us. In our political and civil life as well as in both business and in industry, we cannot return to the old pre-war conditions, even if we so desired. We have no alternative but on the one hand to hold fast to that which was good in the past, and on the other hand to reach out and grasp the good which has come from the war, and welding the two together to press forward to the readjustment of our political, social and economic conditions.

In standing today on the narrow strait which divides the past from the future, we must, like the Roman god
Janus, look backward, but at the same time we must look forward.

The present is no time and there is no occasion for revolutionary action or for untried experiments in government and in industry. This is a time, however, for careful analysis and painstaking consideration of the fundamental aspirations, the underlying principles and the far-reaching ideals, of our democracy, or, in other words, of the self-governing republic which has come down to us through the generations. It is the time to take stock of ourselves, and wherever necessary to readjust the conditions of political and industrial life of the present day in the light of the principles and aspirations of the forefathers. If we will take the time to do this, we shall proceed with wisdom. We shall then have a progressive, safe and certain mode of procedure for the future. If we do not do this, we shall invite disaster. We shall intensify existing untoward conditions for which our children shall have to suffer, and for which they shall be pressed to find a remedy.

\section{Existing Menace of Living Conditions}

The greatest menace with which the country is confronted today, not only industrially but politically and socially as well, arises from the pressure of living costs on the great mass of wage earners in the basic industries. This condition of affairs intensifies the more fundamental causes of industrial unrest and the consequent dislocations in industry and recurrent stoppage of 
work or breaks in the continuity of production. Unless living conditions are ameliorated, widespread industrial conflict may result before proper and safe action can be taken which will afford a basis of procedure for stabilizing industry, accelerating production and guaranteeing industrial peace. The really great danger to the public under present conditions is the extreme attitude, on the one hand, of certain backward employers and legislators who are still evidently doing their thinking on a pre-war basis, and, on the other hand, the extreme agitation of certain labor leaders who are trying to disrupt existing labor organizations and to take away the control of labor from liberal but sane leaders.

\section{Significance of Profiteering}

The abnormal conditions created by the war, as were to be expected, greatly increased prices or the cost of living. The withdrawing of men from industrial and agricultural activities to armed conflict, the diversion of industrial facilities to the manufacture of munitions and war essentials, the destruction of capital and commodities and the restriction upon agriculture in the zones of conflict, or, in other words, destruction, restricted production and unproductive consumption, reduced pre-existing stocks of goods and made additional accumulations more difficult, thus bringing about an excess of demand for commodities over the supply available. The net result was scarcity values and constant rises in prices during and since the war. This situation has been further affected by the war-time inflation in money and credit and in the deterioration of our transportation facilities from the great stress which four years of war operation had put on the railroads.

These have been the underlying, the real determining and unavoidable causes of higher prices for all classes of commodities. While they would have been followed by distress and some elements of unrest among industrial workers, they would undoubtedly, other things being equal, more or less philosophically have been accepted as one of the fortunes of war, and the attempt made to overcome them by productive effort. In the meantime, however, it has been discovered that producers, speculators and distributors have seized upon the scarcity or abnormal conditions which prevailed during the war, and which came out of the war, to exact exorbitant prices and to obtain indefensible and dishonorable profits. Although the exaction of illegitimate profits, or, to use the more common phrase, "profiteering," has not been a basic but a secondary cause of high prices, it has developed a condition of affairs fraught with the greatest significance, for the reason that it is apparent that profiteering must be eliminated before there can be any hope of getting the productive factors in industry together in a coöperative way. This is an essential condition to the acceleration of production or to a return to normal production and normal price conditions.

\section{The Conditron to Increased Pro- DUCTIVITY OF LABOR}

So long as profiteering exists labor cannot be induced to increase its output. Contrary to the general impression, the economic status of labor in our basic industries was impaired by the war. With some few exceptions, wage rates failed to keep pace with the advances in the cost of living. Where rates of pay were actually raised to the point of increased prices, as in the iron and steel industry, it meant merely the perpetuation of entirely inadequate standards of living which prevailed before the war. As a rule, 
however, the deplorable earnings or standards of living of the great mass of industrial workers before the war were not maintained during the war. With the termination of hostilities all government control of industry was abandoned and the hope, which had been based on the obligation of the government to adjust conditions, disappeared. The wage earner was left to shift for himself. Employees in many basic industries undoubtedly felt deeply this situation, and the post-war discontent and lack of coöperation was thus started.

This situation was soon intensified by a still more disturbing influence. Every attempt since the armistice on the part of industrial workers to improve their unfortunate status was met with the claim that to advance rates of pay would be equivalent to increasing prices, and starting another step in the so-called "vicious circle of the increasing cost of living." This soon developed into a distinct propaganda and misrepresentation of labor. The public thoughtlessly gave this propaganda its sanction. Industrial unrest and agitation was further intensified. Wage earners, as a class, felt that aspersions were being cast upon their character and patriotism during the war. They also became very sensitive to the fact that all classes of profiteers were pointing to labor as being responsible for the disgraceful robbery of the public.

\section{Mining and Railroad Strikes}

Caught in this way between the upper and the lower millstones, so to speak, their endurance reached the breaking point. Wages continued to fall further behind skyrocketing prices. Men refused to continue work in certain industries as on the railroads and in the mines. The bituminous coal miners' strike was a reflection of these conditions. The recent countrywide railroad strike was a voluntary expression of this attitude by many classes of employees. Men with long years of service and accompanying seniority and other rights suddenly, against the protest of Brotherhood and Union leaders, stopped work or left the railroads, to enter other industries. The inadequacies of railway wages are now the fundamental cause of restricted transportation facilities. The same conditions prevail in some of our other industries. Unless they are corrected no one can tell what the result may be. Under-paid men are a menace from a social and political as well as an industrial standpoint. Under these conditions, in brief, it has become evident that if conservative and enlightened leadership in the labor movement is to continue, industrial workers must not only secure financial relief, but labor also must be freed from the charge of profiteering which had been dishonorably placed upon it. By the same analysis, it is equally and perhaps more significantly true that the production of which we are in such grievous need cannot be secured until labor is assured that its increased productive efficiency will not be absorbed by profiteers. If labor can be shown that increased production will be followed by lower prices, or in other words, greater real wages, one of the greatest obstacles to maximum production will have been eliminated.

\section{Waste and Extravagance}

In addition to the impairment of industrial morale, probably the next greatest contributing factor to the untoward economic conditions which have followed the war is the widespread waste and extravagance among all classes of the people. Its elimination is obviously necessary to our 
economic regeneration. It has been caused primarily by improper concentration and accumulation of wealth since the beginning of the war, and had its origin and derives its primary impetus at present in the lavish expenditures of war-made and postwar-made millionaires. Their example has been contagious. Those who should have known better have set the example. It has spread to all classes of the population. Extravagance and waste among or excessive demands by industrial workers cannot be checked so long as profiteering producers and distributors are lavishly dissipating the wealth which they illegitimately obtained during the travail and grief of our people.

A necessary preliminary, therefore, to all other measures-as a matter of fact, the first step in the process of reconstruction and stability and acceleration of production--is the stopping of profiteering. There can be no permanent hope or program until profiteering is eliminated. Because of the pressure of the high cost of living, the profiteer has not only become an obstacle to the resumption of normal industrial activities but an actual industrial and social menace as well.

\section{Need for Coöperation Between Employers and Employees}

With the allaying of discontent arising from profiteering and unjustifiable prices, a more fundamental evil must also be rectified before there can be any satisfactory degree of stabilization and continuity in production. The fact cannot be missed that industry is in the same position that our failure to accept the Treaty of Peace has forced upon the nations of the world. There is no accepted basis of procedure. Employers and employees, as a whole, are actually or potentially at war with each other. The condi- tions affecting one principle effective to productive coöperation need only be mentioned in order to illustrate the present impossible situation-the principle of organization and representation of industrial employees. The union labor movement demands recognition as a preliminary to coöperation. A large group of employers are attempting to evade union recognition by the formation of shop committees and the application of various local schemes of employees' representation. Another large body of employers wish to maintain an industrial autocracy without recognition to their employees on any terms. And thus the conflict and friction extends throughout the whole range of industrial relations and conditions. Under these conditions, if industry is not headed for disaster, thoughtful students at least cannot see any earnest of successful productive effort in the future.

Shortly after the signing of the armistice, industrial conferences were assembled under the auspices of the governments of Great Britain and the Dominion of Canada, and certain underlying principles relative to industrial relations were accepted by labor and capital as a basis of industrial procedure. A similar effort was made in this country, but without success. It was found impossible to secure an agreement between employers and employees. It then became evident that whatever action was taken would have to come from the public, and in accordance with this conclusion, a second conference was called last winter by President Wilson, composed entirely of eminent representatives of the public. The report of this body has been made, embodying certain principles which they have sanctioned as essential to industrial progress, economic justice and the public welfare. The conference has also recommended 
machinery for the adjustment of industrial disputes. Senator Kenyon, chairman of the Senate Committee on Education and Labor, has also introduced a joint-resolution providing for the establishment of joint-boards for the adjustment of industrial controversies together with regulatory principles or a code which shall be mandatory upon these boards in reaching their decisions. The Senate Committee is now holding hearings and considering both Senator Kenyon's plan of procedure and the Report of the President's Second Industrial Conference.

\section{Necessity for an Industrial Code}

The permanent hope for the future, not only to those directly engaged in industry, but also to all other classes of our people, lies in wise, constructive, industrial statesmanship and action by the Congress along the lines which have already been placed before Senator Kenyon's Committee. Increased production has become a national necessity, if we are to maintain American standards of living, pay the vast debt incurred as the result of the war, insure our domestic tranquility and discharge our international obligations. Obviously, we cannot hope to restore a normal production, to say nothing of attaining maximum production, so long as there is constant irritation and friction, with frequent economically disastrous conflicts between capital and labor. To promote and to preserve industrial peace, therefore, to insure equal and exact justice to both elements in industry and to safeguard the public interests as well, the Congress of the United States should enact at once an industrial code wherein there shall be defined and promulgated the fundamental principles which shall govern the relations of capital and labor with respect to:
1. The right of both labor and capital to organize;

2. The right of labor to a living wage;

3. The right of capital to a fair return;

4. The right of collective bargaining;

5. The right of labor to a voice in the control of industry;

6. The requiring of both labor and capital to fulfill their contractural obligations;

7. The hours of labor;

8. The rights and relations of women in industry;

9. The right of the public to be protected against economic disturbances, threatening the general welfare, which result from disagreements and conflicts between capital and labor.

Such an industrial code, together with the creation of the machinery necessary for the determination and adjustment of industrial disputes upon the basis and by the application of the principles enunciated in the code, will go far toward stabilizing industry in all lines.

Its enactment can be brought about only through a compromise of the selfish demands and contentions of both capital and labor, and that compromise must be affected on the basis that the public interest overshadows any group interest. Opposition to such legislation may be expected from both elements in industry, and this opposition will probably be predicated on the theory that we should have the least possible governmental interference with business and industry. The plan contained in the Court of Industrial Relations, as passed recently, by the Kansas legislature is unacceptable because it forces compulsory 
adjustments without any safeguards to capital and labor. The labor provisions of the Esch-Cummings bill relative to railroad disputes furnishes a more acceptable precedent, because they afford a more or less imperfect code or standard for the voluntary adjudication of controversies by a specified mode of procedure. A more comprehensive underlying set of principles or standards, together with a series of joint industrial boards, culminating in a national labor board for the interpretation and application of the fundamental law, the code, or the industrial bill of rights-by whatever term it may be called-is essential to an orderly and reconstructed industry. Without such action, there can be but small hope for industrial stability, continuity, or the productiveness which is so greatly needed.

\section{New Conception of Industry}

Thoughtful men will undoubtedly agree that the sentiment of this country and of the world is for progress along the lines suggested. Not the least beneficial result of the world war has been the exploding of a number of age-old aphorisms. One such exploded aphorism is that one to the effect that the best form of government is that which governs least - the Gibraltar of the advocates of the doctrine of laissezfaire. The phenomena of profiteering alone demonstrate the danger of letting the individual alone-giving him a free hand-for we have seen that too often it makes a freebooter of him; and there is no place in orderly society for freebooters.

Such a general program as has been outlined would not only reduce prices and profiteering, and bring about relief from the high cost of living, but would also be in accord with the attitude of the general mass of the people toward business and industry which has been a distinct outgrowth of the war. There can be no doubt that a new conception of industry has been formed by labor and by a large part of the general public. Prior to the war, industry was being conducted primarily for profit, the theory being that by competition and by the free play of economic forces, the greatest advantage to the greatest numberlabor, capital and the public-would be accomplished. On the other hand, during and since the war, the idea has been gaining ground and growing in force and acceptance, that in reality industry is a social institution. In its most conservative form this idea finds expression in the claim that industry should not be conducted in a spirit of relentless, economic, self-interest for profit, but while the stimulus of profit should beretained and the fundamental rights of labor and capital should be protected and conserved, industrial promotion, expansion and operation should also be a social service and subordinated at least to democratic ideals and institutions, and to the general welfare of the people. 